\title{
The Bambuí Health and Aging study (BHAS): prevalence of risk factors and use of preventive health care services
}

\author{
Maria Fernanda Lima-Costa, ${ }^{1,2,3}$ Sandhi M. Barreto, ${ }^{1,2,3}$ Elizabeth Uchôa, ${ }^{1,2,3}$ \\ Josélia O. A. Firmo, ${ }^{1,2}$ Pedro G. Vidigal, ${ }^{2,3}$ and Henrique L. Guerra ${ }^{1,2}$
}

ABSTRACT Objective. To describe, for the first time in Brazil, the prevalence of risk factors and the use of preventive health care services among adults 60 years and older.

Methods. This population-based study was conducted during 1996-1997 in the state of Minas Gerais, in the town of Bambui, which is located in the municipality of the same name. In 1996 the town had 14950 inhabitants. For the study, all the town's residents aged $\geq 60$ years were selected, along with a comparison sample of persons aged 18-59 years. Data were gathered using interviews and physical examinations.

Results. Of the 1742 inhabitants of the town of Bambui aged $\geq 60$ years, 1606 (92.2\%) participated in the interview and 1495 (85.8\%) were examined (blood pressure, anthropometric measurements, and blood tests). Among the 1020 younger adults selected for the survey, 909 of them (89.1\%) participated in the interview, and 820 of them (80.4\%) underwent the physical examination. The prevalence of the following risk factors was higher among older adults than among younger adults: physical inactivity $(47.7 \%$ vs. $28.0 \%)$; blood pressure $140-159 \mathrm{mmHg}$ (systolic) or 90-99 mmHg (diastolic) (25.8\% vs. 8.7\%); blood pressure $\geq 160$ $\mathrm{mmHg}$ (systolic) or $\geq 100 \mathrm{mmHg}$ (diastolic) $(19.1 \%$ vs. $4.1 \%$ ); total cholesterol $\geq 240 \mathrm{mg} / \mathrm{dL}$ $(40.6 \%$ vs. $9.8 \%)$; and blood glucose $\geq 126 \mathrm{mg} / \mathrm{dL}$ (12.4\% vs. $2.2 \%)$. The daily consumption of fruits and vegetables was similar among the older adults and the younger ones $(51.9 \%$ and $51.7 \%)$, as was also body mass index $\geq 25 \mathrm{~kg} / \mathrm{m}^{2}$ (51.6\% and $\left.56.2 \%\right)$. Smoking was lower among the older adults (18.7\%) than among the younger ones (31.1\%). The proportion of participants whose blood pressure had been checked in the preceding year was high $(86.8 \%$ among the older adults and $61.2 \%$ among the younger ones), suggesting that the high prevalence of uncontrolled hypertension was not due to limited access to health care.

Conclusions. For a long time it was believed that the kinds of risk factors that we found in the urban section of the municipality of Bambui were public health problems only in large Brazilian cities. Around 72\% of the municipalities in Brazil have $\leq 20000$ inhabitants, and these smaller municipalities contain some 19\% of the country's entire population. The high prevalence of various risk factors among the older and younger adults in Bambui indicates a great need for health promotion and disease prevention actions. More research is needed to find out whether our results in Bambui reflect the reality of other small towns in Brazil.

Key words Health surveys, health of the elderly, risk factors, health services, disease control and prevention.

1 Núcleo de Estudos em Epidemiologia e Antropologia do Envelhecimento, Belo Horizonte, Minas Gerais, Brasil.

2 Fundação Oswaldo Cruz, Centro de Pesquisas René Rachou, Belo Horizonte, Minas Gerais, Brasil.
Send correspondence to: Maria Fernanda LimaCosta, Laboratório de Epidemiologia e Antropologia Médica, Centro de Pesquisas René Rachou, Fundação Oswaldo Cruz, Av. Augusto de Lima
1715, 30.190.002, Belo Horizonte, Minas Gerais, Brasil; e-mail: costa@cpqrr.fiocruz.br

3 Universidade Federal de Minas Gerais, Faculdade de Medicina, Belo Horizonte, Minas Gerais, Brasil. 
In Brazil older adults are growing rapidly both in number and as a proportion of the country's overall population. Between 1991 and 1996 the number of inhabitants $\geq 60$ years old increased $8.2 \%$, by 1.7 million people $(1,2)$. In 1996 the leading causes of death among these older Brazilians were cardiovascular diseases (1463 deaths/100 000 population), malignant neoplasms (512/100 000), and respiratory diseases (477/100 000). Together, these three causes accounted for $63.8 \%$ of the total deaths among these older adults. For each of these groups of causes, the highest mortality rates were found for cerebrovascular and ischemic heart diseases among males and females; malignant neoplasms of the lung, trachea, and bronchus, as well as prostate cancer among males; breast cancer and malignant neoplasms of the stomach among females; and chronic obstructive pulmonary disease and pneumonia among both males and females (3).

Most of the above-mentioned causes of death could be reduced by health promotion and disease prevention actions. For example, modifiable risk factors that account in part for premature/ avoidable mortality from cardiovascular diseases during later life include smoking, excessive alcohol consumption, physical inactivity, obesity, hyperlipemia, and poor control of hypertension and diabetes (4). Smoking is also an important risk factor for malignant neoplasms of the lung, trachea, and bronchus as well as for chronic obstructive pulmonary disease and pneumonia (5). Secondary prevention, by early diagnosis, is the best way to reduce the mortality due to breast and prostate cancers (6). Vaccination protects against pneumonia and influenza (4).

In order to estimate the needs of older adults for health promotion and disease prevention activities, information is needed on the distribution of risk factors and the use of preventive health services among these persons. In Brazil there have been few population-based epidemiologic studies of older adults. Further, to our knowledge, none of these studies has pro- vided information on risk factors and the use of preventive health care services (7-11).

In this study we used data from the Bambuí Health and Aging Study (BHAS) (12) to describe the prevalence of selected risk factors and the use of preventive health services among older Brazilian adults. Because maintaining health into old age requires investments during earlier stages of life, we compared the above-mentioned data with data obtained from younger adults living in the same community.

\section{MATERIALS AND METHODS}

\section{Study area}

The Bambuí Health and Aging study (BHAS) is a population-based cohort study of older adults living in the town of Bambuí, which is in the southeastern Brazilian state of Minas Gerais. The town of Bambuí is located in the municipality of the same name. In 1991 the municipality had a population of 20573 inhabitants, and the urban area (the town of Bambuí) had a population of 15032 (1). Life expectancy in the municipality was 70.2 years, and $75 \%$ of deaths were among people aged $\geq 50$ years. The main economic activities of the area are agriculture and trading. The town has one doctor per 1000 inhabitants, with one general hospital with 62 beds.

In the municipality of Bambuí in 1996 the main causes of death were stroke (category I60-I69 in the International Statistical Classification of Diseases and Related Health Problems, Tenth Revision (ICD-10) of the World Health Organization; death rate, 110.0 per 100 000), Chagas' disease (ICD-10: B57; death rate, 61.4 per 100000 ), ischemic heart disease (ICD-10: I20-I25; death rate, 42.5 per 100000 ), and chronic obstructive pulmonary disease (ICD-10: J43, J44; death rate, 18.9 per 100000 ). Chagas' disease used to be endemic in the Bambuí area. Because transmission of Trypanosoma cruzi was only interrupted around 20 years ago, the prevalence of infection among the aged remains high, with a high mortality rate due to Chagas' disease in the town (13).

\section{Study population}

To identify participants for the study, the research team carried out a complete census in the town in 1996 and found a population of 14950 inhabitants. All 1742 town residents aged $\geq 60$ years were selected to participate in the study. A nonreplaceable simple probabilistic sample of 1020 out of 8899 inhabitants aged 18-59 years was also selected (12). This sample size was sufficient to estimate a prevalence of risk factors/use of health services $=0.50$, with a confidence interval $(\mathrm{CI})=0.95$, losses $=0.20$, and precision $=0.03(14)$. All the older and younger study participants were interviewed and underwent physical examinations (blood tests, blood pressure measurements, and anthropometric measurements).

\section{Interview}

In this study we considered the following variables: 1 ) demographics (age, sex), 2) lifestyle (smoking, consumption of fruits and vegetables, physical activity during leisure time, and self-rated physical activity), and 3) use of preventive health care services (frequency of checking of blood pressure and cholesterol). The interview used a precoded structured questionnaire.

Current smokers were defined as those who reported having smoked $\geq 100$ cigarettes during their lifetime and who currently smoked. Consumption of fresh fruits or vegetables was assessed by the following question: How often did you eat fresh fruits or vegetables during the last 12 months? Physical activity during leisure time was assessed by the following: During your leisure time in the last 30 days, how often did you walk for exercise and/or do any sport and/or any other kind of exercise for at least 30 minutes? Self-rated physical activity was assessed by this question: 
Which of the following sentences best defines your habits in daily living? Those who answered that they remained seated during most of the day and rarely walked were classified as having a low level of physical activity (sedentary). Those who answered that they remained standing or walked much during the day, and sometimes carried heavy packages, were classified as having an intermediate level of physical activity. The remaining cases were classified as having a high level of physical activity.

Regarding the use of preventive health care services, two variables were considered: 1) number of years since last blood pressure check (When was your blood pressure last checked?) and 2) blood cholesterol checked at any point (Has your blood cholesterol ever been checked?).

When an older participant was unable to be interviewed because of a cognitive deficit or for some other health reason, a proxy respondent was used (12).

\section{Physical examinations}

The first blood pressure (BP) measurement was performed 30 or more min after the last caffeine intake or cigarette smoked, and after at least $5 \mathrm{~min}$ of initial rest. Two more measurements were taken at 2-min intervals. BP was considered as the arithmetic mean of the second and third measurements. Elevated blood pressure stage 1 was considered as 140-159 mmHg (systolic) or $90-99 \mathrm{mmHg}$ (diastolic) and stage 2 as $\geq 160 \mathrm{mmHg}$ (systolic) or $\geq 100 \mathrm{mmHg}$ (diastolic) (15).

We performed the anthropometric measures with the participants wearing light clothes and no shoes. We defined overweight as body mass index (BMI) (weight/height squared) $\geq 25$ $\mathrm{kg} / \mathrm{m}^{2}$ and obesity as $\geq 30 \mathrm{~kg} / \mathrm{m}^{2}(16)$. All measures were performed by specially trained health technicians, using standard equipment (12)

The blood tests included biochemical analysis of fasting total cholesterol and blood glucose, using an auto- mated analyzer (12). The following cutoffs were used to define high levels of cholesterol and of blood glucose: $\geq 240 \mathrm{mg} / \mathrm{dL}$ and $\geq 126 \mathrm{mg} / \mathrm{dL}$, respectively $(17,18)$. Blood samples were scheduled in advance, with a recommended 12-hour fast; we offered snacks and coffee afterwards.

All the interviews and physical examinations were carried out between October 1996 and August 1997. We obtained signed voluntary informed consent from all the participants. Further details on the study methods and procedures are in Lima e Costa et al. (12).

\section{Data analysis}

Data analyzed was based on the Pearson chi-square statistic and on crude and adjusted odds ratios (ORs) and their 95\% confidence intervals (Woolf's method) (19). The odds ratios were adjusted by sex using multivariate logistic regression (20). The analysis was carried out using Stata statistical software (21).

\section{RESULTS}

Of the 1742 inhabitants of the town of Bambuí aged $\geq 60$ years, 1606 $(92.2 \%)$ participated in the interview and 1495 (85.8\%) were examined (blood pressure, anthropometric measurements, and blood tests). Proxy respondents were necessary for $5.6 \%$ of the older adults interviewed. Among the 1020 younger adults (18-59 years old) who were selected for the survey, 909 of them $(89.1 \%)$ participated in the interview, and 820 of them (80.4\%) underwent the physical examination.

The median age of the older-adult participants was 68 years (range = 60-95), and for the younger participants it was 36 years (range $=18-59$ ). The proportion of females was higher among the older participants than among the younger ones, $60.0 \%$ versus $54.6 \%(P=0.008)$.

The distribution of selected lifestyle risk factors among older and younger adults is presented in Table 1. Current smoking was less frequent among the older adults than among the younger

TABLE 1. Percentages of older and younger adults with selected lifestyle risk factors, and corresponding odds ratios (ORs), with 95\% confidence intervals (Cls), Bambuí, Minas Gerais, Brazil, 1996-1997

\begin{tabular}{|c|c|c|c|c|}
\hline \multirow[b]{3}{*}{ Lifestyle characteristic } & \multicolumn{2}{|c|}{ Age group (years) } & \multirow{3}{*}{$\begin{array}{l}\text { Crude OR } \\
(95 \% \mathrm{Cl})\end{array}$} & \multirow{3}{*}{$\begin{array}{l}\text { Adjusted OR } \\
(95 \% \mathrm{Cl})^{\mathrm{a}}\end{array}$} \\
\hline & \multirow{2}{*}{$\begin{array}{c}\geq 60 \\
(n=1606) \\
\%\end{array}$} & \multirow{2}{*}{$\begin{array}{c}18-59 \\
(n=909) \\
\%(95 \% \mathrm{Cl})\end{array}$} & & \\
\hline & & & & \\
\hline \multicolumn{5}{|l|}{ Current smoker } \\
\hline No & 81.3 & $68.9(65.9-71.9)$ & 1.0 & 1.0 \\
\hline Yes & 18.7 & $31.1(28.1-34.1)$ & $0.5(0.4-0.6)$ & $0.5(0.4-0.6)$ \\
\hline \multicolumn{5}{|l|}{$\begin{array}{l}\text { Daily consumption of fresh } \\
\text { fruits or vegetables }\end{array}$} \\
\hline Yes & 48.1 & $48.3(45.1-51.5)$ & 1.0 & 1.0 \\
\hline No & 51.9 & $51.7(48.5-54.9)$ & $1.0(0.8-1.2)$ & $0.9(0.8-1.1)$ \\
\hline \multicolumn{5}{|l|}{$\begin{array}{l}\text { Frequency of exercise } \\
\text { during leisure time in } \\
\text { past } 30 \text { days }\end{array}$} \\
\hline$\geq 3$ times a week & 12.8 & $16.7(14.3-19.1)$ & 1.0 & 1.0 \\
\hline $1-2$ times a week & 7.7 & $16.1(13.7-18.5)$ & $0.6(0.5-0.9)$ & $0.6(0.5-0.9)$ \\
\hline Never & 79.5 & $67.2(64.1-70.3)$ & $1.6(1.2-2.0)$ & $1.5(1.2-1.9)$ \\
\hline \multicolumn{5}{|l|}{$\begin{array}{l}\text { Self-rated physical activity } \\
\text { in daily living }\end{array}$} \\
\hline High & 5.6 & $19.7(17.1-22.3)$ & 1.0 & 1.0 \\
\hline Intermediate & 46.6 & $52.3(49.0-55.6)$ & $3.1(2.4-4.1)$ & $3.1(2.3-4.2)$ \\
\hline Low (sedentary) & 47.7 & $28.0(25.1-30.9)$ & $6.0(4.5-8.0)$ & $6.0(4.4-8.0)$ \\
\hline
\end{tabular}

adjusted OR = crude OR adjusted by sex. 
FIGURE 1. Prevalence of lifestyle risk factors, according to age and sex, Bambuí, Minas Gerais, Brazil, 1996-1997
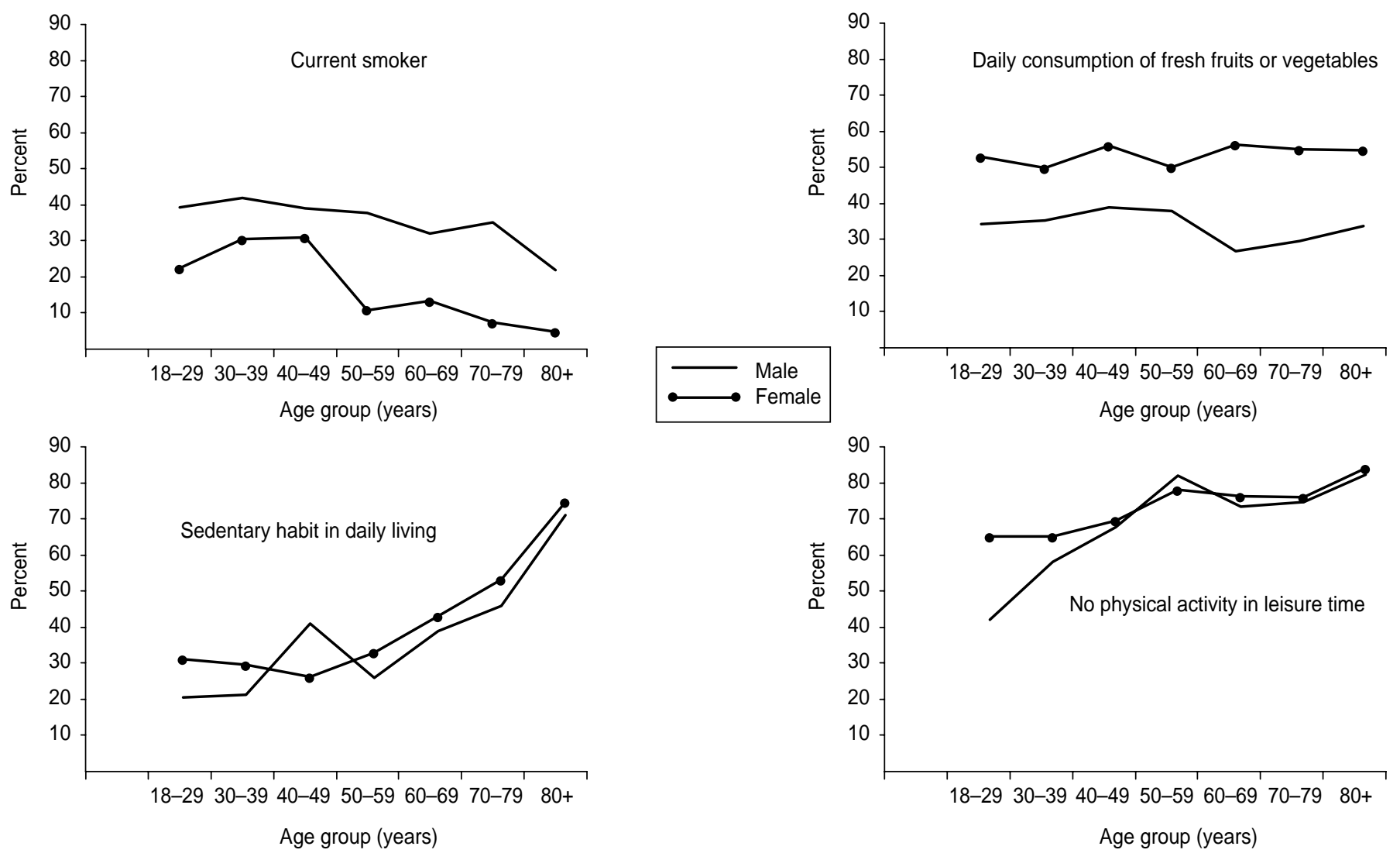

adults, $18.7 \%$ vs. $31.1 \%$. The prevalence of daily consumption of fresh fruits or vegetables was similar among the older and younger adults. A large majority of the persons in both age groups reported doing no exercise during their leisure time in the previous 30 days. In terms of their self-rated daily physical activity, $5.6 \%$ of the older adults reported themselves as having a high level of physical activity, $46.6 \%$ reported they had an intermediate level, and $47.7 \%$ reported a low level. Among the younger adults, the corresponding figures for high, intermediate, and low levels of daily physical activity were $19.7 \%, 52.3 \%$, and $28.0 \%$. The prevalences of four different lifestyle risk factors, according to age and sex, are presented at Figure 1.

Table 2 shows the distribution of high blood pressure, body mass index, total cholesterol, and blood glucose among the older and younger adults.

TABLE 2. Percentages of older and younger adults with selected health-related conditions, and corresponding odds ratios (ORs), with 95\% confidence intervals (Cls), Bambuí, Minas Gerais, Brazil, 1996-1997

\begin{tabular}{|c|c|c|c|c|}
\hline \multirow[b]{3}{*}{ Health-related condition } & \multicolumn{2}{|c|}{ Age group (years) } & \multirow{3}{*}{$\begin{array}{c}\text { Crude OR } \\
(95 \% \mathrm{Cl})\end{array}$} & \multirow{3}{*}{$\begin{array}{c}\text { Adjusted OR } \\
(95 \% \mathrm{Cl})^{\mathrm{a}}\end{array}$} \\
\hline & $\begin{array}{c}\geq 60 \\
(n=1495)\end{array}$ & $\begin{array}{c}18-59 \\
(n=820)\end{array}$ & & \\
\hline & $\%$ & $\%(95 \% \mathrm{Cl})$ & & \\
\hline \multicolumn{5}{|l|}{ High blood pressure ${ }^{b}$} \\
\hline No & 55.1 & $87.2(84.9-89.5)$ & 1.0 & 1.0 \\
\hline Stage 1 & 25.8 & $8.7(6.8-10.6)$ & $4.7(3.6-6.2)$ & $4.7(3.6-6.2)$ \\
\hline Stage 2 & 19.1 & $4.1(2.7-5.5)$ & $7.3(5.0-10.5)$ & $7.4(5.1-10.7)$ \\
\hline \multicolumn{5}{|l|}{ Body mass index $\left(\mathrm{kg} / \mathrm{m}^{2}\right)$} \\
\hline$<25.00$ & 51.6 & $56.3(52.9-59.7)$ & 1.0 & 1.0 \\
\hline $25.01-29.99$ & 35.4 & $30.7(27.5-33.9)$ & $1.2(1.0-1.5)$ & $1.2(1.0-1.5)$ \\
\hline$\geq 30.00$ & 13.0 & $13.0(10.7-15.3)$ & $1.0(0.8-1.4)$ & $1.0(0.8-1.4)$ \\
\hline \multicolumn{5}{|l|}{$\begin{array}{l}\text { Total cholesterol } \\
\geq 240 \mathrm{mg} / \mathrm{dL}\end{array}$} \\
\hline No & 59.4 & $90.2(88.2-92.2)$ & 1.0 & 1.0 \\
\hline Yes & 40.6 & $9.8(7.8-11.8)$ & $6.3(4.9-8.1)$ & $6.3(4.9-8.2)$ \\
\hline \multicolumn{5}{|l|}{ Blood glucose $\geq 126 \mathrm{mg} / \mathrm{dL}$} \\
\hline No & 87.6 & $97.8(96.8-98.8)$ & 1.0 & 1.0 \\
\hline Yes & 12.4 & $2.2(1.2-3.2)$ & $6.3(3.8-10.3)$ & $6.2(3.8-10.2)$ \\
\hline
\end{tabular}

a Adjusted OR $=$ crude OR adjusted by sex.

${ }^{b}$ High blood pressure stage 1 is $140-159$ (systolic) or $90-99 \mathrm{~mm} \mathrm{Hg}$ (diastolic); stage 2 is $\geq 160$ (systolic) or $\geq 100 \mathrm{mmHg}$ (diastolic). 
FIGURE 2. Prevalence of individuals with selected health-related conditions, according to age and sex, Bambuí, Minas Gerais, Brazil, 1996-1997
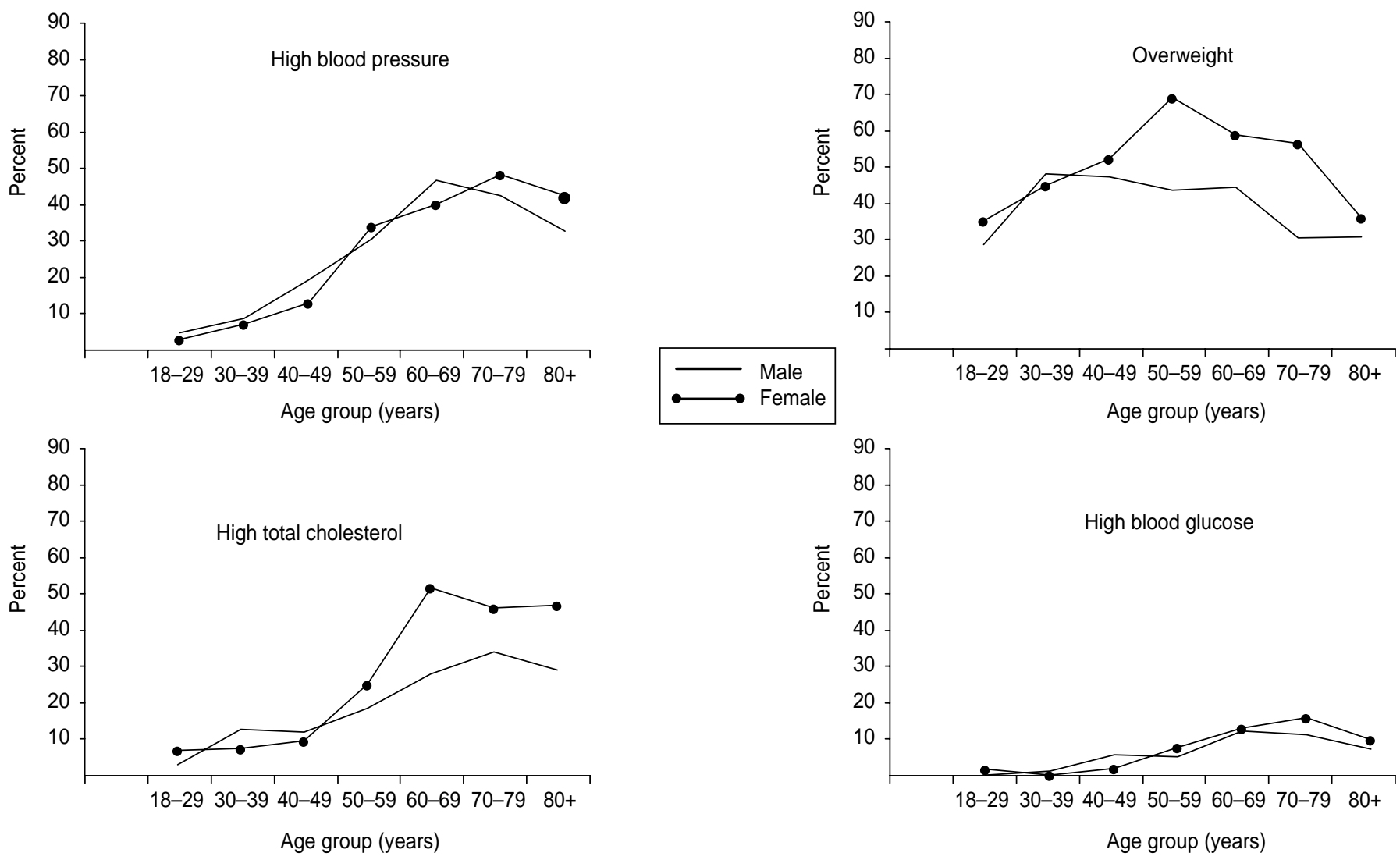

As expected, the prevalence of high blood pressure at any stage was higher among the older adults than among the younger ones, $44.9 \%$ vs. $12.8 \%$. Fasting total cholesterol $\geq 240 \mathrm{mg} / \mathrm{dL}$ and blood glucose $\geq 126 \mathrm{mg} / \mathrm{dL}$ were also strongly associated with older age. Overweight was slightly more frequent among the older participants $(35.4 \%)$ than among the younger adults $(30.7 \%)$. The prevalence of obesity was the same in the two age groups, $13.0 \%$. Figure 2 presents the distributions of high blood pressure, overweight, total cholesterol $\geq 240$ $\mathrm{mg} / \mathrm{dL}$, and blood glucose $\geq 126 \mathrm{mg} / \mathrm{dL}$ by age and by sex.

Table 3 shows the distribution of selected preventive health care measures among older and younger adults. Those aged $\geq 60$ were more likely to have had their blood pressure checked in the preceding year and to have had their cholesterol checked during their lifetime.

\section{DISCUSSION}

The high prevalence of risk factors that we found among older and young adults indicates a great need for health promotion, risk prevention, and adequate treatment in the study community. As expected, many of the studied risk factors were significantly more frequent among older inhabitants than among younger ones.

Previous studies have assessed the prevalence of selected risk factors among younger adults in large cities in Brazil. One study, of São Paulo, investigated persons 15-59 years old (22). Another study, of Porto Alegre, was of persons 15-64 years old (23). Despite methodological differences and/or possible differences in age distribution, the estimated prevalences of high blood pressure and of physical inactivity during leisure time among younger adults in Bambuí were reasonably similar to those for São Paulo and Porto Alegre. However, in Bambuí the percentages of persons who were obese or who reported a low (sedentary) level of physical activity were lower than what was found in these two larger cities. The estimated prevalence of current smoking among young adults in Bambuí was lower than in São Paulo and Porto Alegre, but it was still twice the level recommended by the United States' Healthy People 2000 national health promotion and disease prevention objectives (24). Our results agree with the above- 
TABLE 3. Percentages of older and younger adults using selected preventive health care measures, and corresponding odds ratios (ORs), with $95 \%$ confidence intervals (Cls), Bambuí, Minas Gerais, Brazil, 1996-1997

\begin{tabular}{|c|c|c|c|c|}
\hline \multirow[b]{3}{*}{ Indicator } & \multicolumn{2}{|c|}{ Age group (years) } & \multirow{3}{*}{$\begin{array}{l}\text { Crude OR } \\
(95 \% \mathrm{Cl})\end{array}$} & \multirow{3}{*}{$\begin{array}{l}\text { Adjusted OR } \\
\quad(95 \% \mathrm{Cl})\end{array}$} \\
\hline & $\begin{array}{c}\geq 60 \\
(n=1606)\end{array}$ & $\begin{array}{c}18-59 \\
(n=909)\end{array}$ & & \\
\hline & $\%$ & $\%(95 \% \mathrm{Cl})$ & & \\
\hline \multicolumn{5}{|c|}{$\begin{array}{l}\text { No. of years since blood } \\
\text { pressure was last checked }\end{array}$} \\
\hline$>5$ & 3.8 & $19.1(16.4-21.8)$ & 1.0 & 1.0 \\
\hline $1-5$ & 9.4 & $18.9(16.2-21.6)$ & $2.6(1.8-3.8)$ & $2.6(1.8-3.7)$ \\
\hline$<1$ & 86.8 & $61.2(57.9-64.5)$ & $7.4(5.5-10.1)$ & $7.4(5.4-10.1)$ \\
\hline \multicolumn{5}{|c|}{$\begin{array}{l}\text { Cholesterol checked } \\
\text { during lifetime }\end{array}$} \\
\hline No & 52.8 & 77.2 (76.0-78.4) & 1.0 & 1.0 \\
\hline Yes & 47.2 & $22.8(21.6-24.0)$ & $3.0(2.5-3.6)$ & $3.0(2.5-3.5)$ \\
\hline
\end{tabular}

${ }^{a}$ Adjusted OR = crude OR adjusted by sex.

mentioned studies in Brazil $(22,23)$ in terms of males showing higher levels of current smoking and of physical activity than do females.

With respect to the prevalence of smoking and physical activity among older adults, to our knowledge there are no other comparable data for Brazil. Among older adults in the United States, depending on educational level, the prevalence of smoking varies from $12 \%$ to $18 \%$ for persons 65-75 years old and from 5\% to $8 \%$ among those $\geq 75$ years old (24). Among the older adults in the United States, persons with $\geq 8$ years of schooling are more likely to be current smokers. In our study the prevalence of current smokers among those aged 60-79 years (20\%) and among those $\geq 80$ years old $(11 \%)$ was reasonably similar to what was observed in the United States for older adults with lower education levels. In Bambuí we found a decrease in the prevalence of smoking with age. This decrease, also observed in the United States (24), may be a consequence of one or more of three factors: an increase in the number of persons who quit smoking as they get older, a cohort effect (different generations may smoke differently), and a survival bias (the premature death of smokers).

The prevalence of physical inactivity during leisure time among the older adults in Bambuí (78.6\% and $86.8 \%$ among those aged $60-79$ and $\geq 80$ years, respectively) was much higher than that observed for older adults in the United States (34\% and $44 \%$ among those aged $65-74$ and $\geq 75$ years, respectively) (24). These differences between Brazil and the United States are large, and are thus unlikely to be explained by methodological differences. Cultural patterns might be an alternative explanation. As previously shown, physical activity during leisure time is not common in Brazil, even among young adults living in large cities, such as São Paulo (22) and Porto Alegre (23), and there are no reasons to believe that it would be different in a small town such as Bambuí.

Around half of the participants in our study reported daily consumption of fresh fruits or vegetables. This proportion was higher among females, and it did not vary with age. Among older persons in the United States, about one-third ate fruits and vegetables $\geq 5$ times daily. This proportion increased with age, and it was higher among females than among males (24). In our study, because the frequency of consumption of fruits and vegetables in the previous 12 months was self-reported, the data are subject to recall bias. Aging might influence a person's ability to recall eating habits, and it is possible that our results un- derestimate the proportion of older adults in Bambuí with a low consumption of fruits and vegetables.

Studies differ from each other in their estimates of the prevalence of high blood pressure among older adults, depending on such factors as the age and race of the group studied, the blood pressure cutoff points used, and the number of measurements made. Broadly speaking, in the United States the prevalence of hypertension among those older than 65 exceeds $25 \%$ among whites and $30 \%$ among African-Americans (25). In our study the prevalence of high blood pressure stage 1 or higher was above $40 \%$ among those aged $\geq 60$ years. Among males the prevalence of high blood pressure increased until age 60-69 years and decreased thereafter. Among females, the prevalence of high blood pressure increased up to age 70-79.

High blood pressure is a leading risk factor for coronary heart disease, congestive heart failure, stroke, ruptured aortic aneurysm, renal disease, and retinopathy. Unrecognized and uncontrolled hypertension are important indicators of the need for preventive actions in the community. Assuming that the goals for blood pressure lowering are systolic blood pressure $<140 \mathrm{mmHg}$ and diastolic blood pressure $<90 \mathrm{mmHg}(15,25)$, there were many older adults in Bambuí who needed evaluation for adequate treatment of hypertension. The United States' Healthy People 2000 effort recommended increasing to $\geq 90 \%$ the proportion of adults who have had their with blood pressure measured during the preceding 2 years (6).

In our study, $87 \%$ of the older adults and $61 \%$ of the younger ones had had their blood pressure measured in the preceding year, indicating that access to measurement was not a problem for them. Further investigations are needed to examine the determinants of high blood pressure and the appropriate corresponding treatment among older adults in Bambuí.

Excess bodyweight is a risk factor for coronary artery disease, some cancers, diabetes, hypertension, and os- 
teoarthritis (26). The prevalence of self-reported overweight (BMI $\geq 25$ $\mathrm{kg} / \mathrm{m}^{2}$ ) among older adults in the United States is higher among males than among females, and it decreases with age, for example, from 58\% to $46 \%$ among whites aged $65-74$ years and $\geq 75$ years, respectively (24). In comparison to those figures for the United States, in Bambuí, using physical measurements, we found lower levels of overweight $(45 \%$ among those aged 60-79 and 33\% among those aged $\geq 80$ years). In contrast to older adults in the United States (24), in our study the prevalence of overweight was higher among females than among males. This finding in Bambuí agrees with studies in large Brazilian cities showing a higher prevalence of overweight among younger females than among younger males $(22,23)$.

Regarding total cholesterol levels, $41 \%$ of the older adults in Bambuí and $10 \%$ of the younger ones presented fasting total cholesterol $\geq 240 \mathrm{mg} / \mathrm{dL}$. Among females the prevalence of total high cholesterol levels increased up to age 60-69 years and decreased thereafter. Among males, the prevalence of hypercholesterolemia increased up to age 70-79. These patterns in Bambuí are reasonably similar to ones observed among adults in the United States (27), except that the decline began at a later age in the Bambuí population.

There is considerable evidence that fasting total cholesterol is a risk factor for coronary heart disease (CHD) in both males and females aged < 75 years, with less support for that among those aged $\geq 75$ years. The screening and treatment of individuals aged $>75$ years for hyperlipidemia (particularly those without overt CHD) remain controversial $(17,28)$. The Healthy People 2000 effort in the United States recommended routine measurement of fasting total cholesterol and high-density lipoprotein cholesterol in all adults aged $\geq 20$ years at least once every 5 years (26). In Bambuí only $47 \%$ of older adults and $23 \%$ of younger ones had ever had their cholesterol checked.

The prevalence of diabetes mellitus (previous diagnosis and/or blood glucose $\geq 126 \mathrm{mg} / \mathrm{dL}$ ) in the general population of the United States is around $7 \%$, and is higher among males than among females (18). The highest prevalence rates, around $20 \%$, are found among those aged $\geq 60$. We do not know the prevalence of diabetes in Bambuí. However, the prevalence of high blood glucose and thus of those who need further evaluation for diagnosis and/or treatment was 12\% among older adults and 2\% among younger ones. The highest prevalence level for males, $12 \%$, was among those aged 60-69. For females the highest prevalence level, $15 \%$, was among those aged 70-79. Unfortunately, we do not have information for Bambuí concerning the frequency of checking blood glucose. The American Diabetes Association recommends that all individuals older than 45 years be tested for diabetes every 3 years, with the fasting glucose level being the recommended test (18).

We took a number of steps in the BHAS to avoid bias (12). These included encouraging participation, collecting information in a doubleblinded manner, assessing the reliability of the data gathered, standardizing procedures and instruments, and conducting exhaustive training of field work and laboratory teams. Internal validity was assured because the participation rate was high. Also, the older and younger participants were similar to their respective overall town populations in terms of gender, age, marital status, monthly family income, and education (12).

On the other hand, our and other population-based cross-sectional studies of older adults have two major limitations: 1) older participants are survivors (i.e., those exposed to risk factors have a higher probability of dying prematurely) and 2) participants are noninstitutionalized elderly, with those living in the community tending to be healthier. In Bambuí there are no institutions for older adults. Nevertheless, one cannot discard the possibility of survival bias. Differential misclassification of self-reported variables is another potential bias in this study because the accuracy of memory seems to vary between younger and older adults. The survival or information bias would tend to reduce the prevalence of risk factors among older participants.

Of the 4475 municipalities in Brazil, $72 \%$ of them have $\leq 20000$ inhabitants. These smaller municipalities together contain $19 \%$ of the total population of Brazil, or around 27 million persons (2). Information on the health and related conditions of inhabitants of small Brazilian municipalities is very limited. For a long time, it was believed that risk factors for chronic noninfectious diseases were public health problems in large cities, and that small municipalities should devote their public resources to controlling infectious diseases. However, our results indicate that the prevalences of most risk factors for chronic noninfectious diseases in Bambuí were high, pointing to a critical need for health promotion, disease prevention activities, and adequate treatment of diabetes and hypertension. Further research is needed to verify whether our results can be generalized to other small towns in Brazil.

Acknowledgements. This study was supported by the Financiadora de Estudos e Projetos (FINEP), Brazil. M.F.F. Lima e Costa, S.M. Barreto, and E. Uchôa are fellows of the Brazilian Research Council (CNPq). The authors would like to thank the people of Bambuí for their hospitality and cooperation with the study. 


\section{REFERENCES}

1. FIBGE-Fundação Instituto Brasileiro de Geografia e Estatística. Censo demográfico: 1991. Rio de Janeiro: IBGE; 1992.

2. FIBGE-Fundação Instituto Brasileiro de Geografia e Estatística. Censo demográfico: 1996. Rio de Janeiro: IBGE; 1997.

3. Lima e Costa MFF, Guerra HL, Barreto SM, Guimarães RM. Diagnóstico da situação de saúde da população idosa brasileira: um estudo da mortalidade e das internações hospitalares públicas. Informe Epidemiológico do SUS 2000;9(1):23-41.

4. Desai MM, Zhang P, Hennessy CH. Surveillance for morbidity and mortality among older adults: United States, 1995-1996. Mor Mortal Wkly Rep CDC Surveill Summ 1999; 48(8):7-25.

5. United States, Department of Health and Human Services. Reducing the health consequences of smoking: 25 years of progress. A report of the Surgeon General. Rockville, Maryland, United States: DHHS, Public Health Service, Centers for Disease Control, Center for Chronic Disease Prevention and Health Promotion, Office on Smoking and Health; 1989. (DHHS Publication No. (CDC) 89-8411).

6. Janes GR, Blackman DK, Bolen JC, Kamimoto LA, Rhodes L, Caplan LS, et al. Surveillance for use of preventive health-care services by older adults, 1995-97. Mor Mortal Wkly Rep CDC Surveill Summ 1999;48(8):51-88.

7. Ramos LR. Growing old in São Paulo, Brazil: assessment of health status and social support of elderly people from different socio-economic strata living in the community [Ph.D. thesis]. London: University of London; 1987.

8. Veras R. A survey of the health of elderly people in Rio de Janeiro, Brazil [Ph.D. thesis]. London: University of London; 1992.

9. Ramos LR, Rosa TE, Oliveira ZM, Medina MC, Santos FR. Perfil do idoso em área metropolitana na região sudeste do Brasil: resultado de inquérito domiciliar. Rev Saude Publica 1993;27:87-94.

10. Ramos LR, Toniolo J, Cendoroglo MS, Garcia JT, Najas MS, Perracini M, et al. Two-year follow-up study of elderly residents in S. Paulo, Brazil: methodology and preliminary results. Rev Saude Publica 1998;32:397-407.
11. Coelho Filho JM, Ramos LR. Epidemiologia do envelhecimento no nordeste do Brasil: resultados de inquérito domiciliar. Rev Saude Publica 1999;33:445-453.

12. Lima e Costa MFF, Uchôa E, Guerra HL, Firmo JOA, Vidigal PG, Barreto SM. The Bambui Health and Ageing Study (BHAS). Methodological approach and preliminary results of a population-based cohort study of the elderly in Brazil. Rev Saude Publica 2000;34(2):126-135.

13. Lima e Costa MFF, Barreto SM, Guerra HL Firmo JOA, Uchôa E, Vidigal PG. Ageing with Trypanosoma cruzi infection in a community where the transmission has been interrupted. Int J Epidemiol. Forthcoming.

14. Dean AG, Dean JA, Coulombier D, Brendel KA, Smith DC, Burton AH, et al. Epi Info, version 6.0: a word processing database and statistics program for epidemiology on microcomputers. Atlanta, Georgia, United States: Centers for Disease Control and Prevention; 1994.

15. The sixth report of the Joint National Committee on Detection, Evaluation, and Treatment of High Blood Pressure. Arch Intern Med 1997;157(21):2413-2446.

16. United States, National Heart, Lung, and Blood Institute. Clinical guidelines on the identification, evaluation, and treatment of overweight and obesity in adults: the evidence report. Bethesda, Maryland: Department of Health and Human Services, National Institutes of Health; 1998.

17. Katzel LI, Goldberg AP. Dyslipoproteinemia. In: Hazzard WR, Blass JB, Ettinger WH, Halter JB, Ouslander JG, eds. Principles of geriatric medicine and gerontology. 4th ed. New York: The McGraw Hill Co. Inc; 1999. p. 1013-1028.

18. Halter JB. Diabetes mellitus. In: Hazzard WR, Blass JB, Ettinger WH, Halter JB, Ouslander JG, eds. Principles of geriatric medicine and gerontology. 4th ed. New York: The McGraw Hill Co. Inc; 1999. p. 991-1011.

19. Armitage P, Berry G. Statistical methods in medical research. Oxford: Blackwell Scientific Publications; 1987.

20. Hosmer DW, Lemenshow S. Applied logistic regression. New York: John Wiley and Sons; 1989.
21. Stata Corporation. Stata statistical software [computer program]. Release 6.0. College Station, Texas, United States: Stata Corporation; 1997.

22. Rego RA, Berardo FAN, Rodrigues SSR, Oliveira ZMA, Oliveira MB, Vasconcellos CV, et al. Fatores de risco para doenças crônicas não transmissíveis: inquérito domiciliar no município de São Paulo, SP (Brasil): metodologia e resultados preliminares. Rev Saude Publica 1990; 24(4):277-285.

23. Duncan BB, Schmidt MI, Polanczyk CA, Homrich CS, Rosa RS, Achutti AC. Fatores de risco para doenças não transmissíveis em área metropolitana na região sul do Brasil: prevalência e simultaneidade. Rev Saude Publica 1993;27(1):43-48.

24. Kamimoto LA, Eston NA, Maurice E, Hustern CG, Macera CA. Surveillance for five health risks among older adults-United States (1993-1997). MMWR 1999;48(SS-8):89-130.

25. Applegate WB. Hypertension. In: Hazzard WR, Blass JB, Ettinger WH, Halter JB, Ouslander JG, eds. Principles of geriatric medicine and gerontology. 4th ed. New York: The McGraw Hill Co. Inc; 1999. p. 713-720.

26. Pi-Sunyer FX. Medical hazards of obesity. Ann Intern Med 1993;119:655-660.

27. Johnson CL, Rifkind BM, Sempos CT, Carroll MD, Bachorik PS, Brie RR, et al. Declining serum total cholesterol levels among US adults. The National Health and Nutrition Examination Surveys. JAMA 1993;269:3002.

28. Manolio TA, Pearson TA, Wenger NK, BarrettConnor E, Payne GH, Harlan WR. Cholesterol and heart disease in older persons and women. Review of an NHLBI workshop. Ann Epidemiol 1992;2:161-176.

Manuscript received 18 September 2000. Revised version accepted 29 March 2001. 
RESUMEN Objetivos. Describir por primera vez en Brasil la prevalencia de factores de riesgo y el uso de servicios de salud preventivos por parte de los adultos de edad $\geq 60$ años.

Métodos. Este estudio basado en la población se realizó en 1996-1997 en la ciudad

El Estudio de Bambuí sobre la Salud y el Envejecimiento (BHAS): prevalencia de factores de riesgo y uso de los servicios de salud preventivos de Bambuí, localizada en el municipio del mismo nombre, Estado de Minas Gerais. En 1996 la ciudad tenía 14950 habitantes. Para este estudio se seleccionaron todos los residentes en la ciudad con $\geq 60$ años y una muestra de comparación formada por personas de 18 a 59 años. Los datos registrados se obtuvieron mediante entrevistas y exámenes físicos.

Resultados. De los 1742 habitantes de la ciudad de Bambuí de edad $\geq 60$ años, 1606 $(92,2 \%)$ participaron en la entrevista y 1495 (85,8\%) fueron examinados (mediciones antropométricas y de la tensión arterial y pruebas de sangre). De los 1020 adultos más jóvenes seleccionados para el estudio, 909 (89,1\%) participaron en la entrevista y 820 $(80,4 \%)$ fueron examinados. La prevalencia de los siguientes factores de riesgo fue mayor en los adultos de edad $\geq 60$ años que en los adultos más jóvenes: inactividad física (47,7 frente a 28,0\%); tensión sistólica de 140-159 mm Hg o diastólica de 90-99 $\mathrm{mm} \mathrm{Hg}(25,8$ frente a $8,7 \%)$; tensión sistólica $\geq 160 \mathrm{~mm} \mathrm{Hg}$ o diastólica $\geq 100 \mathrm{~mm} \mathrm{Hg}$ $(19,1$ frente a $4,1 \%)$; colesterol total $\geq 240 \mathrm{mg} / \mathrm{dL}(40,6$ frente a $9,8 \%)$, y glucemia $\geq 126$ $\mathrm{mg} / \mathrm{dL}(12,4$ frente a $2,2 \%)$. El consumo diario de frutas y vegetales fue similar en ambos grupos (51,9 frente a 51,7\%), al igual que el índice de masa corporal $\geq 25 \mathrm{~kg} / \mathrm{m}^{2}$ $(51,6$ frente a $56,2 \%)$. El consumo de tabaco fue menor en el grupo de más edad (18,7\%, frente a $31,1 \%$ en los adultos más jóvenes); con la proporción de participantes cuya tensión arterial había sido registrada durante el año anterior ocurrió lo contrario $(86,8 \%$, frente a $61,2 \%$ en los adultos más jóvenes), lo cual indica que la mayor prevalencia de la hipertensión no controlada no se debió a limitaciones en el acceso a la atención sanitaria.

Conclusiones. Durante mucho tiempo se ha creído que los factores de riesgo encontrados en este estudio en la zona urbana del municipio de Bambuí solo constituían problemas de salud pública en las grandes ciudades brasileñas. Cerca del $72 \%$ de los municipios de Brasil tienen $\leq 20000$ habitantes y estos pequeños municipios representan cerca del 19\% de la población total del país. La alta prevalencia de varios factores de riesgo en los adultos ancianos y más jóvenes de Bambuí señala la gran necesidad de acciones de promoción de la salud y de prevención de enfermedades. Son necesarias más investigaciones para determinar si estos resultados obtenidos en Bambuí reflejan la realidad de otras pequeñas ciudades de Brasil.

Risk factors are based only on associations demonstrated in epidemiological studies; hence they may be directly causative, secondary manifestations of more basic underlying metabolic abnormalities or early symptoms of the disease.

[Los factores de riesgo se basan exclusivamente en las asociaciones demostradas en los estudios epidemiológicos; por lo tanto pueden ser directamente causales, manifestaciones secundarias de anormalidades metabólicas fundamentales, o síntomas tempranos de la enfermedad.]

William B. Kannel

"An overview of the risk factors for cardiosvacular disease" Prevention of coronary heart disease: practical management of the risk factors, 1983 